\title{
DOI: 10.7596/taksad.v6i3.912
}

Citation: Köşk, Ü., \& Gürbüz, A. (2017). Ailelerin Tatil Karar Sürecine Gençlerin Etkileri: Ankara İli Örneği. Journal of History Culture and Art Research, 6(3), 630-649. doi:http://dx.doi.org/10.7596/taksad.v6i3.912

\section{Ailelerin Tatil Karar Sürecine Gençlerin Etkileri: Ankara İli Örneği The Effects of the Youngs on the Family Vacation Decision Process: Ankara Case Study}

\begin{abstract}
Ahmet Gürbüz ${ }^{1}$, Ülker Köşk ${ }^{2}$
Abstract

Individuals who are members of a social group exhibit behaviors that may be similar or identical to that of the social group. It can be said that the individuals in a familiy, like in a social group, also have the same or similar thoughts, habits and behaviors. Having similar thoughts, habits and behaviors is the result of the individuals in the group being affected by each other.

The individuals in the family can be influenced by each other in the decision-making process as well as with the many areas. This influence is multilinear, and we must say that it is possible for each of the family members to be potentially affected individually by all the members of the family. This research examines how families are influenced by their children's thoughts during vacation decision-making. The universe of the research is young people aged 15-24 who reside in Ankara. As in most areas, families can be influenced by their children's thoughts and ideas during holiday decision-making. In this research, according to all these information, it researched in the city of Ankara to examine the effects decision-making process of the families of young people aged 15-24. A total of 1160 surveys were conducted in the research and 15 surveys were not included in the study for various reasons. The results of the questionnaires were analyzed using SPSS 22.0 program interpreting the data obtained from the remaining 1145 questionnaires.
\end{abstract}

Keywords: Family, Decision, Decision Making, Teens, Generation, Generation gap, Family vacation.

\footnotetext{
${ }^{1}$ Karabük Üniversitesi, İktisadi ve İdari Bilimler Fakültesi, Karabük. E-mail: agurbuz@karabuk.edu.tr

${ }^{2}$ Karabük Üniversitesi, Sosyal Bilimler Enstitüsü, Karabük. E-mail: ulkerceceli@hotmail.com
} 


\section{Öz}

Bir sosyal gruba mensup olan bireyler, sosyal grubun davranış biçimi ile benzer ya da aynı sayılabilecek davranışlar sergilerler. Sosyal bir grup olan ailedeki bireylerin de aynı düşüncelere, alışkanlıklara ve davranışlara sahip oldukları söylenebilir. Benzer düşünce, alışkanlık ve davranışlara sahip olmanın temelinde grup içindeki bireylerin birbirlerinden etkilenmelerinin yer aldığı söylenebilir.

Ailedeki bireyler birçok alanda olduğu gibi karar verme sürecinde de birbirlerinden etkilenebilirler. $\mathrm{Bu}$ etkilenme çok yönlü bir etkilenme olup aile bireylerinden herbirinin potansiyel olarak ailenin tüm bireylerinden ayrı ayrı etkilenmesinin mümkün olduğunu söylememiz gerekir. $\mathrm{Bu}$ araştırma, tatil karar verme sürecinde ailelerin, çocuklarının düşüncelerinden ne şekilde etkilendiklerini incelemektedir. Çalışmanın evrenini, Ankara’da ikamet eden 15-24 yaş arası gençler oluşturmaktadır. Araştırmada toplam 1160 anket uygulanmış olup çeşitli nedenlerle 15 anket çalışmaya dâhil edilmemiştir. Geriye kalan 1145 anketten elde edilen verilerin yorumlanması için SPSS 22,0 veri analiz programı kullanılarak anket sonuçları analiz edilmiştir.

Anahtar Kelimeler: Aile, Karar, Karar Verme, Gençler, Kuşak, Kuşaklararası ilişki, Tatil karar1.

\section{Giriş}

Ailede yaşayan kişi sayısı tek kişi sayısından önemli ölçüde daha fazla olduğunu düşünecek olursak, ailelerin karar verme alanında araştırma yapmak tüketici davranışları hakkında bilgi sahibi olmak için oldukça önemlidir. Günümüzde ailelerin karar verme şekilleri genellikle tüketici davranışlarını inceleyen araştırmacılar tarafından incelenmiş ve daha fazla teorik inceleme gereksinim duyulmaktadır. Ailelerin karar verme davranışları üzerine yapılan önceki araştırmalarda öncelikle üç önemli konu üzerine odaklanılmıştır. Bunlar; aile üyelerinin kararları, aile üyelerinin kararlarının sonuçları ve son olarak hangi aile üyesinin faktörlerle ilgili karar verdiği üzerine odaklanılmıştır. Satın alma karar sürecinde etkili olan faktörlerden aile ve bireyin dahil olduğu sosyal sınıfa göre kişilerin kararları şekillenmektedir (Aydın, 2007: 105).

$\mathrm{Bu}$ çalışmanın temel amacı ailelerin tatil karar sürecine gençlerin etkilerini tespit etmektir. $\mathrm{Bu}$ doğrultuda genç nüfusun yoğun olarak yaşadığı Ankara ili uygulama alanı olarak tercih edilmiş ve hazırlanan anket çalışmasıyla ailelerin tatil karar sürecine gençlerin etkileri ölçülmeye çalışılmıştır. Çalışmanın birinci bölümünde aile kavramına ve karar verme sürecine 
ilişkin bilgilere yer verilmiştir. Çalışmanın ikinci bölümünde ise ailelerin tatil karar sürecine etkilerine yönelik yapılan çalışmanın sonuçlarına yer verilmiştir.

\section{Literatür}

Aile, biyolojik ilişkiler neticesinde insan neslinin devamını sağlayan ve toplumsallaşma sürecinin ilk olarak ortaya çıtı̆̆ı, ikili ilişkilerin belirli kurallar çerçevesinde sağlandığı, toplumda meydana getirilmiş manevi ve maddi zenginliklerin kuşaklar arası aktarılmasını sağlayan, psikolojik, ekonomik, biyolojik, hukuksal toplumsal ve benzeri yönleri bulunan toplumsal bir kurumdur (Sayın, 1990: 2).

Aile kavramı genel geçerliği olan, sosyal grup ile aile fertleri arasındaki ilişkileri içeren, örf ve adetleri, gelenek ve göreneklere sahip olan sosyal bir kurumdur (Nirun, 1994: 17). Görevleri bakımından aileyi üç farklı açıdan incelemek mümkündür (Yörükoğlu, 2007);

- $\quad$ Aile her şeyden önce eşlerin duygusal ve bedenen gereksinimlerini karşılayan yasal bir birliktir,

- $\quad$ Aile, ortak amacı, çıkarları, inançları ve kuralları olan inanç topluluğudur.,

- $\quad$ Aile, çocukların beslenip bakıldığı ve eğitildiği ortamdır.

Aile içerisinde yaşayan bireylerin aynı ev ortamını paylaşmaları sonucunda bireyler arasında yüz yüze ilişkiler söz konusu olduğundan; insanın varlığını sürdürmesi için kurduğu sosyal ilişkilerin en önemlisi aile içerisinde gerçekleşmektedir. Ailenin dağılmasını engelleyen, ailenin yapısının güçlü kalmasını sağlayan aile bireyleri arasındaki açık ve sürekli iletişim, aileye ait olma hissi, aile bireyler arasındaki sevgi ve saygı paylaşımı, aile içerisinde kazanılan sorumlulukların ve rollerin yerine getirilmesidir (Önder, 2003: 16-18).

Geniş aile kavramı, tek bir hanede birden çok kuşağın birlikte yaşadığı bir aile yapısıdır. Bugünlerde geniş aileye duyulan özlem, büyük ölçüde, Batılı, tarım dışı toplumlarda bu tür geniş ailelere çok az rastlanmasından dolayıdır. Fakat karı/koca ailelerinde bile daha geniş akrabalığın getirdiği yükümlülükler etkili olabilir (Marshall, 1999: 265- 266).

Baba, anne ve onların henüz evlenmemiş çocuklarından meydana gelen bu ailelere çekirdek aile denilmektedir. Çekirdek aile, ailede yaşayan birey sayısına göre değil aynı zamanda yapı olarak da geniş aileden oldukça farklıdır. Çekirdek aile, kentlerde üretim ve yaşam koşullarına göre ortaya çıkmaktadır. Kırsal kesimlerde aile, çoğunlukla bireylerin birlikte çalışıp birlikte üretim yaptıkları ekonomik bir birimdir. 
Karar verme, örgütsel ve yönetsel bir süreçtir. Yönetseldir; çünkü yöneticilerin sorumluluklar1 arasında karar verme de vardır. Bir kişinin yöneticilik vasıflarına çoğu zaman onun karar verme yetkisinin olup olmadığına bakarak karar verilir. Karar verme yetkisi olup bu yetkiyi kullanamayan kişileri yönetici olarak değerlendirmek doğru değildir. $\mathrm{Bu}$ nedenle, yöneticilerin kişisel sermayesi olarak, karşılaştıkları problemler karşısında vermiş oldukları doğru kararlar görülebilir (Can, Tuncer, Ayhan, 2002: 207).

Örgütseldir; çünkü modern topluluklarda karar, tek başına yöneticileri aşan, takım, grup ve hatta çoğu zaman bilgisayar yardımıyla verilen bir süreçtir. Yöneticiler, yönetsel ve örgütsel süreçlerin tam merkezinde olduğu için çevresindeki faktörlerden ayrı düşünülmemektedir. Bu nedenle yöneticilerin vermiş olduğu kararlar hem örgütten hem çevreden etkilenir ve her ikisini de etkileyerek örgütün davranışlarını yönlendirir ve biçimlendirir. Yöneticiler, örgütsel işlerini karar vererek gerçekleştirmektedirler. Verdikleri bu kararlar örgütün hareketlerini biçimlendirir ve yönlendirir (Can, Tuncer, Ayhan, 2002: 207).

Tüketiciler satın alma kararı verirken 'Neyi ne kadar satın almam lazım? Ne kadar ve ne zaman satın almam lazım? Nasıl satın almam lazım? " gibi sorulara cevap aramaktadırlar. Tüketici satın alma karar süreci de Problemin veya ihtiyacın fark edilmesi, bilgi toplama, alternatiflerin değerlendirilmesi, satın alma kararının verilmesi ve satın alma kararı sonrası değerlendirme aşamalarından oluşmaktadır (Koç, 2013: 573).

İhtiyacın fark edilmesi aşamasında tüketiciler zihinsel, dış uyaranlar ve fizyolojik ihtiyaçların aracılığıyla ihtiyacın farkına varmaktadırlar. Bilgi toplama aşamasında ise, tüketiciler ortaya çıkan ihtiyacın nasıl bir ürün veya hizmetle giderileceğine dair karar verilebilmesi için bilgi toplar. Alternatiflerin değerlendirilmesinde ise, toplanan bilgiler sonucunda değerlendirme yapılır. Satın alma kararı ve uygulanması aşamasında ise, tüketiciler kendileri için en uygun olan yerden ürün veya hizmeti satın alırlar. Son aşama olan satın alma sonrası değerlendirme aşamasında ise, ürünün verdiği tatmin, ürünün eksikleri gibi unsurlar ön plandadır (Koç, 2013: 573).

Emir ve Pekyaman (2010), ailelerin konaklama yeri seçiminde çocukların rolüne ilişkin yaptıkları çalışmada ailenin tatil ulaşım aracından, çıkılacak tatile kadar birden fazla ürün grubunun baba, anne ve çocuk ile birlikte karar aldıklarını ancak bazı ürün gruplarında çocukların daha etkili olduklarından bahsetmişlerdir. Konaklama yeri seçiminde çocuklu ailelerin, odalarda çocuk yatağının olması, güvenlik, otelde çocuk menülerinin olması gibi özellikler çalışmalarında ön plana çıkmaktadır.

Şekil 1. Ailelerin satın alma kararına etki modeli

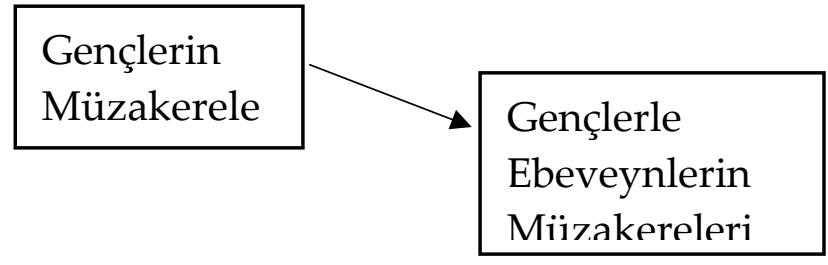




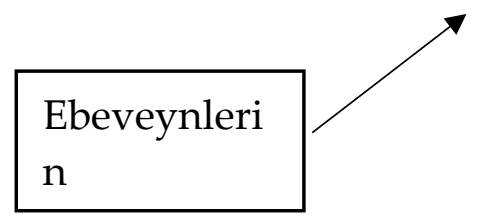

Kaynak: (Tiago, 2013)

$\mathrm{Bu}$ modelin amacı, aile satın alma kararlarında ergenlerin etkilerini, ailenin kullandığı bütün ürün ve hizmetler için satın alma kararlarına göre güncellemek ve bunları aile tatilleri ile ilgili kararlarla karşılaştırmaktır. Ailenin karar verme sürecinin, sosyal, tüketim ve davranışsal yönleri de içeren birçok yönü kapsayan ebeveyn-genç ilişkisine dayandığı kabul edilmektedir (Tiago, 2013).

Kotler (2000), ailede hem gelir elde eden hem de tüketen bireylerin olması nedeniyle aile içindeki satın alma davranışlarının pazarlama yönetimi için önemli olduğunu belirtmektedir. Birey, satın alma davranışında aile üyelerinden etkilenirken aynı zamanda ailenin diğer üyelerini de satın alma kararlarında etkileyebildiği için pazarlama yöneticilerinin, aile üyelerinin tüketim davranışlarını incelemesi gerektiğini savunmaktadır (Kotler 2000: 166).

Yapılan çalışmalarda çocukların aile içinde karar alma sürecindeki etkisi incelendiğinde dört tip aile yapısı oluşturulmuştur (Koç, 2011:311):

$\checkmark \quad$ Otoriter anne-babalar; çocukları üzerinde fazla hâkimiyet kurmaya çalışırlar ve sorgulamadan itaat etmelerini beklerler. Anne-babanın otoriter olduğu ailelerde; çocukların karar alma sürecine katılımının sınırlı olması beklenir.

$\checkmark \quad$ İhmalkâr anne-babalar; çocuklarına uzak kalırlar ve çocukları üzerinde etkili olamaz ve pek kontrol sağlayamazlar.

$\checkmark \quad$ Demokratik aileler; anne-baba ve çocukların haklarının eşit olarak gözetildiği bir atmosfer yaratmaya çalışırlar. Bu ailelerde, çocuklar kendilerini ifade etmeleri ve böylece aile içi karar alma sürecinde aktif olarak katılımları için cesaretlendirilirler.

$\checkmark \quad$ Her şeye izin veren anne-babalar; çocukların tehlikeye düşürmemek kaydıyla, kısıtlamaları olabildiğince kaldırmaya çalışırlar. Bu tür ailelerde, çocukların yetişkinlerle aynı haklara ancak daha az sorumluluğa sahip olduklarına inanırlar.

Turistlerin satın alma karar süresi boyunca turistik davranış önemlidir fakat bu önem turistten turiste değişmektedir (Rızoğlu, 1995: 47). Turistlerin satın alma karar süreçleri beş aşamada ortaya çıkmaktadır. Bunlar (İçöz, 1996: 56):

1. Turistik ürün ya da hizmetlere yönelik ihtiyacın ortaya çıkması,

2. Turistik yerlerdeki ürün veya hizmet tercihlerinin belirlenmesi, 
3. Ürün veya hizmet çeşitleriyle ilgili seçeneklerin değerlendirilmesi,

4. Turistik ürün veya hizmet için verilen satın alma kararı,

5. Satın alma sonucundaki davranışlar

Tablo 1. Tatile Çıkma Kararı için Alınan Diğer Kararlar

\begin{tabular}{|l|l|}
\hline Birincil öncelikli kararlar & $\underline{\text { Íkincil öncelikli kararlar }}$ \\
Tatil yapılacak mı, yapılmayacak mı? & Tatilin türü ne olacak? \\
Tatil ne zaman yapılacak? & Tatilin amacı nedir? \\
Tatil ne kadar sürecek? & \\
Tatilde ne kadar harcama yapılacak? & \\
Tatile kimlerle çıkılacak? & \\
\hline Ücüncül öncelikli kararlar & Dördüncü öncelikli kararlar \\
\hline Tatil nereye yapılacak? & Tatil rezervasyonu nasıl yapıllacak? \\
Tatil hangi konaklama tesisinde yapılacak? & \\
Tatilde yiyecek içecekler nasıl karşılanacak? & \\
Tatilde hangi ulaşım araçlarından yararlanılacak? & \\
Tatil rezervasyonu nasıl yapılacak? & \\
\hline
\end{tabular}

Kaynak: (R1zaoğlu, 2003: 145)

Tatil yapılıp yapılmayacağına, tatilin süresi ve kimlerle tatile çıkılacağı, ne zaman gidileceği ve harcama miktarı turistlerin birincil önceliklerindendir. Tatile çıkma kararı için alınan diğer kararlar ise genelde bu kararlardan sonra verilen kararlardır (Rızaoğlu, 2003).

\section{Yöntem}

Bu araştırmada, son yıllarda gittikçe önem kazanmakta olan ve tüketici olarak önemli bir yere sahip gençlerin ailelerin tatil satın alma kararı üzerine etkileri konusunda çıkarımlarda bulunmak amaçlanmaktadır. Gençlerin, çocukluktan itibaren ailelerin satın alma 
kararlarındaki güçlenen durumu ve satın alma kararındaki etkileri pazarlamacılar açısından oldukça önemli bir konumdadır.

Araştırma için verilerin toplanması aşamasında ilk olarak konu ile ilgili literatür incelenerek, daha önce bu konuyla ilgili yapılmış çalışmalar incelenmiş ve bu doğrultuda araştırma problemi ve kavramsal çerçeve meydana getirilmiştir. Araştırmanın ampirik bölümünde ise, ailelerin tatil karar sürecine gençlerin etkilerini ölçme amacıyla anket yöntemi kullanılmıştır.

Anket ölçeklerinin oluşturulması sürecinde, anket sorularının hazırlanmasında alana yönelik olanı araştırmacı tarafından uzman akademisyenlerin öneri ve görüşleri alınarak gereken düzenlemeler yapıldıktan sonra oluşturulmuştur. Anket, Ankara ilinde yaşamakta olan 15-24 yaş arası gençler üzerinde uygulanmıştır. Çalışmada 15-24 yaş grubu seçilmesinde daha önce yapılan çalışmalarda genelde bu yaş grubu üzerine çalışılması ve Türkiye İstatistik Kurumu (TUIKK) verilerine göre ülkemizde genç nüfus olarak bu yaş aralığının daha yoğun olması etkili olmuştur.

Anket sorularının anlaşılıp anlaşılmadığını tespit etmek amacıyla ön anket uygulanmış ve uygulanan anketlere verilen cevaplar doğrultusunda faktör analizi ve güvenilirlik analizleri uygulanmıştır. Analizler sonucunda elde edilen verilerin değerleri yeterli bulunmuş ve Ankara ilinde yaşayan 15-24 yaş arası 1160 gence anket uygulanmıştır. Uygulanan 1160 anketin 15 adedi çeşitli nedenlerden dolayı çalışmada kullanılmamıştır. Geriye kalan 1145 anketin yüzde doksanı kişilerle yüz yüze görüşülerek uygulanırken yüzde onluk kısım için de kişilere epostayla ulaşılmıştır.

Araştırma kapsamında aralıklı ölçek ile sınıflama ölçeği kullanılmıştır. Sınıflama ölçeğinde gençlerin ve ailelerinin demografik özellikleri ile ilgili değişkenler (Cinsiyet, yaş, eğitim durumu, ne sıklıkla tatile çıktıkları, aile mesleği, ailenin aylık geliri, gençlerin gösterdikleri davranışlar ve tepkiler) sınıflama ölçeği kullanılmıştır. Gençlerin ailelerin tatil karar sürecine etkilerini ölçmek amacıyla Likert Ölçeği’nden faydalanılmıştır. Gençlerin ankette bulunan her bir ifadeye katılım düzeylerini ölçmek amacıyla 5'li Likert tipi (Kesinlikle katılmıyorum, katılmıyorum, kararsızım, katılıyorum, kesinlikle katılıyorum) olan ölçekten yararlanılmıştır.

Araştırma kapsamında, anket sonucunda elde edilen verilerden veri tabanı oluşturulmuştur. Elde edilen veriler güvenilirlik ve faktör analizi uygulanmıştır. Kasier-Meyer-Olkin (KMO) örneklem yeterliliği değişkenler arası korelasyonların faktör analizi yapmak için uygun olup olmadığını test etmektedir. KMO değeri 0 ile 1 arasında değişmektedir. KMO değerinin 1 ve 1' e yakın olması değişkenlerin mükemmel olduğunu göstermektedir. KMO örneklem yeterliliğinin kabul edilebilir olması için alt sınırın 0,50 olması gerekmektedir (Durmuş, 
Yurtkoru ve Çinko, 2016: 80). Bu çalışmada ise KMO değeri 0,837 bulunmuştur. Bu değerin 1'e yakın olması örneklem yeterliliğinin kabul edilebilir olduğunu göstermektedir.

Tablo 2. Kasier- Meyer-Olkin

Kaiser-Meyer-Olkin Measure of Sampling Adequacy. $\quad \mathbf{0 , 8 3 7}$

\begin{tabular}{|c|c|c|c|}
\hline \multirow{2}{*}{$\begin{array}{l}\text { Bartlett's } \\
\text { Sphericity }\end{array}$} & Test & of Approx. Chi-Square & 794,863 \\
\hline & & Df & 120 \\
\hline & & Sig. & 0,000 \\
\hline
\end{tabular}

Cronbach's Alpha ankette yer alan sorular arasında korelasyona bağımlı uyumu gösteren değerdir. Cronbach's Alpha değeri faktörlerin altında yer alan soruların toplam güvenilirlik düzeyini göstermektedir. Cronbach's Alpha değeri 0,70'in üstünde olması ölçeğin güvenilir olduğu anlamına gelmektedir. Ancak, ankette yer alan soru sayısı az ise bu sınır 0,60 ve üstü değer olarak kabul edilmektedir (Durmuş, Yurtkoru ve Çinko, 2016: 89). Ailelerin tatil kararı sürecine gençlerin etkilerini ölçmek amacıyla 20 ifadeye yönelik Cronbach Alpha değeri 0,853 olarak bulunmuştur. İfadelere Faktör analizi uygulandıktan sonra yeni ailelerin tatil karar sürecinde gençlerin etkisi ölçeğine ilişkin güvenirlik katsayısı, ölçeğe ait Cronbach's Alpha değerlerinin 0,909 olarak hesaplandığı görülmektedir. $\mathrm{Bu}$ değerler ölçeğin güvenirliğinin $0,80<$ Cronbach's Alpha $<1,0$ arasında olduğundan güvenirliliğin yüksek düzeyde olduğunu gösterir. Her bir maddenin toplam korelasyona olan etkileri incelendiğinde 0,30'un altında olan en düşük maddeden başlanarak tek tek ölçekten çıkartılmıştır. Ölçekte 0,30'un altında madde kalmayacak sonucuna ulaşana kadar madde çıkarıldığında ölçeğin son durumu aşağıdaki tabloda verilmiştir.

Tablo 3: Güvenilirlik Analizi

\begin{tabular}{ll} 
Cronbach's Alpha & N of Items \\
\hline 0,909 & 12
\end{tabular}


Ailelerin tatil karar sürecine gençlerin etkileri ile demografik özellikleri arasında anlamlı bir farklılık olup olmadığını tespit etmek amacıyla uygulanan testler sonucunda araştırmada şu hipotezlere cevap aranmıştır. Bunlar:

$\mathbf{H}_{\mathbf{0}}$ : Ailelerin tatil karar sürecinde gençlerin etkisi alt boyutları arasında anlamlı bir ilişki yoktur.

$\mathbf{H}_{1}$ : Ailelerin tatil karar sürecinde gençlerin etkisi alt boyutları arasında anlamlı bir ilişki vardir.

Araştırma kapsamında, gençlerin tatil karar sürecinde, yaş, cinsiyet, eğitim durumu, ailenin mesleği, ailenin gelir durumu, tatile çıkma sıklığı, gençlerin gösterdikleri davranışlar ve tepkiler araştırmanın bağımsız değişkenleri olarak kabul edilmiştir.

\section{Bulgular}

Araştırmaya katılan gençlerin ve ailelerinin demografik özellikleri (Cinsiyet, yaş, eğitim durumu, ne sıklıkla tatile çıktıkları, aile mesleği, ailenin aylık geliri, gençlerin gösterdikleri davranışlar ve tepkiler) yönelik yüzde frekans dağılımı Tablo 4’te yer almaktadır.

Tablo 4: Gençlerin ve Ailelerinin Demografik Özelliklerine Ait Bilgiler

\section{Cinsiyet}

Kadın

Erkek

Toplam

Yaş

$15-17$

$18-20$

$21-23$
Yüzde

Sayı

(\%)

$553 \quad 48,3$

$592 \quad 51,7$

\section{0,0}

Sayı

Yüzde

(\%)

$195 \quad 17,0$

$310 \quad 27,1$

$247 \quad 21,6$ 


\section{Toplam}

Eğitim Durumu

İlköğretim

Ortaöğretim

Ön Lisans

Lisans

Yüksek Lisans

Toplam

Aile Mesleği

Memur

Akademik personel

Sağlık

Asker polis vb

Savcı, hâkim vb

Esnaf

Öğretmen

Diğer
1145100,0

Yüzde

(\%)

$198 \quad 17,3$

$360 \quad 31,4$

$209 \quad 18,3$

24121,0

$137 \quad 12,0$

1145100,0

Sayı Yüzde

(\%)

$173 \quad 15,1$

$180 \quad 15,7$

$154 \quad 13,4$

$147 \quad 12,8$

$126 \quad 11,0$

$123 \quad 10,7$

1129,8

$130 \quad 11,4$ 


\begin{tabular}{|c|c|c|}
\hline Toplam & 1145 & 100,0 \\
\hline Aile Aylık Gelir & Sayı & $\begin{array}{l}\text { Yüzde } \\
\text { (\%) }\end{array}$ \\
\hline 2000 TL ve alt 1 & 103 & 9,0 \\
\hline $2001-4000 \mathrm{TL}$ & 168 & 14,7 \\
\hline 4001- $6000 \mathrm{TL}$ & 267 & 23,3 \\
\hline 6001- $8000 \mathrm{TL}$ & 264 & 23,1 \\
\hline 80001- 10000 TL & 211 & 18,4 \\
\hline 10000 TL ve üzeri & 132 & 11,5 \\
\hline Toplam & 1145 & 100,0 \\
\hline Ürün Alınmadığında Gösterilen Tepki & Sayı & $\begin{array}{l}\text { Yüzde } \\
\text { (\%) }\end{array}$ \\
\hline İstediğim olana kadar ağlarım. & 163 & 14,2 \\
\hline Ailemin mantıklı bir açıklama yapmasını beklerim. & 172 & 15,0 \\
\hline Aileme küserim. & 204 & 17,8 \\
\hline Ailemi ikna etmeye çalışırım. & 178 & 15,5 \\
\hline Ailemi tehdit ederim. & 206 & 18,0 \\
\hline Ailemdeki başka bireyi ikna etmek için çabalarım. & 222 & 19,4 \\
\hline Toplam & 1145 & 100,0 \\
\hline Gençlerin Tatildeki Tepkileri & Sayı & $\begin{array}{l}\text { Yüzde } \\
\text { (\%) }\end{array}$ \\
\hline
\end{tabular}


İstediğim şey alınmadığında tepki göstermem.

İstediğim şey olmadığında tepki gösteririm.

İstediğim şey alınana kadar çabalarım.

İstediğim şeyi almak için harçlık biriktiririm.

İstediğim şeyi almaktan vazgeçerim.
$171 \quad 14,9$

$347 \quad 30,3$

$309 \quad 27,0$

$206 \quad 18,0$

1129,8

\section{Toplam}

Tatile Çıkma Sıklı̆̆ı

Y1lda bir kez

Yılda birkaç kez

2 y1lda bir kez

3 y1lda bir kez

Her yıl yaz aylarında

Her yıl kış aylarında

\section{0,0}

$\begin{array}{ll}\text { Sayı } & \text { Yüzd } \\ & (\%)\end{array}$

$151 \quad 13,2$

$286 \quad 25,0$

$204 \quad 17,8$

$200 \quad 17,5$

$197 \quad 17,2$

1079,3

\section{Toplam}

1145100,0

Araştırmaya katılan gençlerin demografik özellikleri incelendiğinde, \%48,3' ü kadın, \%51,7' si erkeklerden oluşmaktadır. Araştırmaya katılan gençlerin \%17' si 15-17 yaş, \%27,1' i 18-20 yaş, \%21,6’ s1 21-23 yaş, \%34,3’ ü 24 yaş grubunda olduğu belirlenmiştir.

Katılımcıların eğitim düzeylerine baktığımızda, \%17,3' ü ilköğretim, \%31,4' ü ortaöğretim (lise), \%18,3' ü ön lisans, \%21' i lisans, \%12' si yüksek lisans mezunu olarak eğitim 
durumlarını belirtirken, \%15,1' i memur, \%15,7' si akademik personel, \%13,4' ü sağlı, \%12,8' i asker, polis vb., \%11' i savc1, hâkim vb., \%10,7' si esnaf, \%9,8' i öğretmen, \%11,4' ü diğer olarak aile mesleklerini bildirmişlerdir. Araştırmaya katılan kişilerin \%9' u 2000 TL ve alt1, \%14,7' si 2001-4000 TL, \%23,3' ü 4001-6000 TL, \%23,1' i 6001-8000 TL, \%18,4' ü 8001-10000 TL, \%11,5’ i 10000 TL ve üzeri olarak aile gelir durumlarını belirtmişlerdir.

Gençlerin istedikleri ürün alınmadığında ailelerine gösterdikleri tepkiler incelendiğinde, \%14,2'si " İstediğim olana kadar ağlarım", \%15'i " Ailemin mantıklı bir açıklama yapmasını beklerim', \%17,8'i “' Aileme küserim”, \%15,5' i '” Ailemi ikna etmeye çalışırım", \%18'i " Ailemi tehdit ederim”, \% 19,4'ü " Ailemdeki başka bireyi ikna etmek için çabalarım", şeklinde davranışlarını belirtmişlerdir.

Gençlerin tatildeki tepkilerine baktığımızda, katılımcıların \%14,9' u istediğim şey alınmadığında tepki göstermem, \%30,3' ü istediğim şey olmadığında tepki gösteririm, \%27' si istediğim şey alınana kadar çabalarım, \%18' i istediğim şeyi almak için harçlık biriktiririm, $\% 9,8^{\prime}$ i istediğim şeyi almaktan vazgeçerim.

Katılımcıların tatile çıkma sıklığı incelendiğinde \%13,2' si yılda bir kez, \%25' i yılda birkaç kez, \%17,8' i 2 yılda bir kez, \%17,5' i 3 y1lda bir kez, \%17,2' si her y1l yaz aylarında, \%9,3' ü her yıl kış aylarında tatile çıktıklarını belirtmişlerdir.

Çalışmada uygulanan Faktör analizi sonuçlarına göre 12 maddeden oluşan ailelerin tatil karar sürecinde gençlerin etkisi ölçeğinin 3 faktörlü (boyutlu) olduğu görülmektedir. Buda aşağıda çizgi grafiğiyle gösterilmiştir.

Şekil 2: Ailelerin Tatil Karar Sürecinde Gençlerin Etkisi Faktör Analizi Çizgi Grafiği

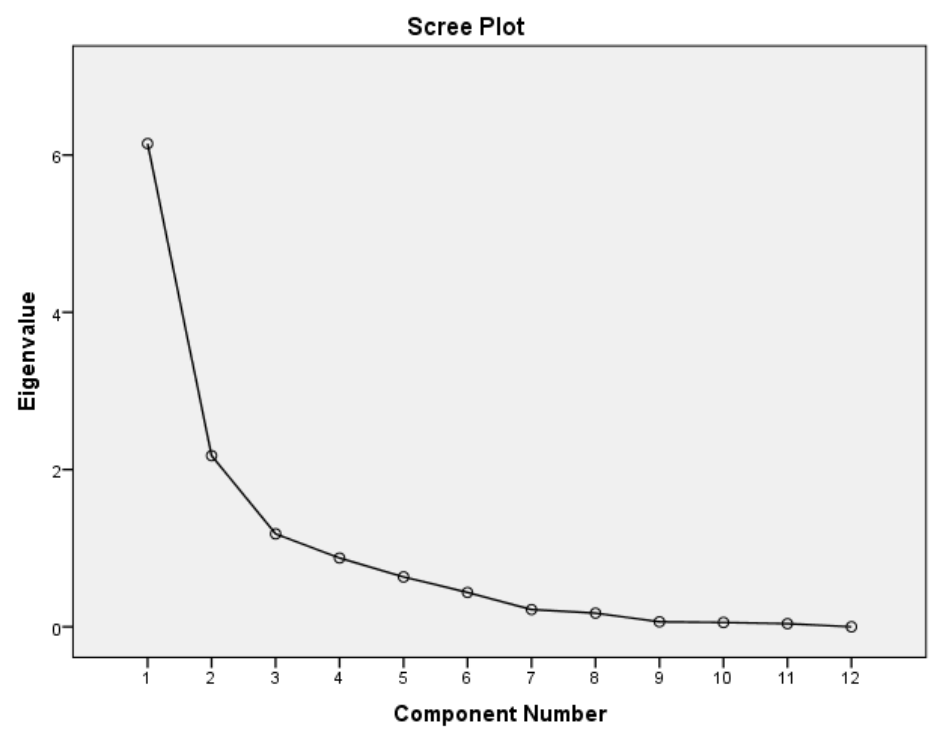


Şekil 1'de görüldüğü gibi Eigenvalues'i 1'den büyük olan 3 faktör söz konusudur. Çizgi grafiğinde üçüncü faktörden itibaren grafiğin eğimini önemli ölçüde kaybetmesi, faktör sayısının üç ile sınırlandırılabileceğini göstermektedir. Bu üç faktör, 'Tatil ihtiyacı ve Bilgi toplama, Tatil süresi planlama ve Tatile çıkma kararı ve Hazırlık" olarak isimlendirilmiştir.

Tablo 5: Ailelerin Tatil Karar Sürecinde Gençlerin Etkisi Ölçeğinin Güvenilirlik Analizi

\begin{tabular}{lll}
\hline & Cronbach's Alpha & Madde Sayısı \\
\hline Tatil İhtiyacı ve Bilgi Toplama & 0,981 & 5 \\
\hline Tatil Süresini Planlama & 0,977 & 3 \\
\hline Tatile Çıkma Kararı ve Hazırlık & 0,775 & 4 \\
\hline
\end{tabular}

12 maddeden oluşan Ailelerin Tatil Karar Sürecinde Gençlerin Etkisi ölçeğine ait alt boyutlarından Tatil İhtiyacı ve Bilgi Toplama ait güvenilirliğin çok yüksek (Cronbach's Alpha=0.981), Tatil Süresini Planlama ait güvenilirliğin çok yüksek (Cronbach's Alpha=0.977), Tatile Çıkma Kararı ve Hazırlık alt boyutuna ait güvenilirliğin yüksek (Cronbach’s Alpha=0.775) olduğu belirlenmiştir.

Tablo 6: Ailelerin Tatil Karar Sürecinde Gençlerin Etkisine İlişkin Ortalama ve Standart Sapma Değerleri

MADDELER

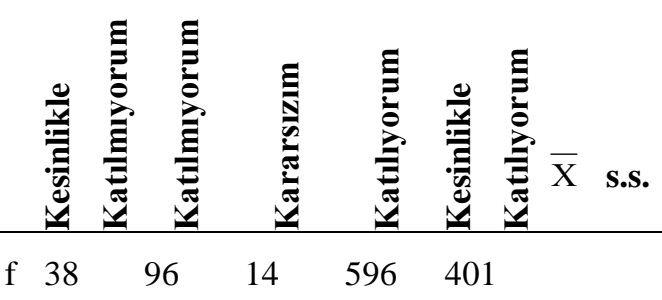

Tatilde nereye gideceğimiz konusunda ailem benim görüşümü önemser.

\% 3,3 $\quad 8,4 \quad 1,2 \quad 52,1 \quad 35,0$

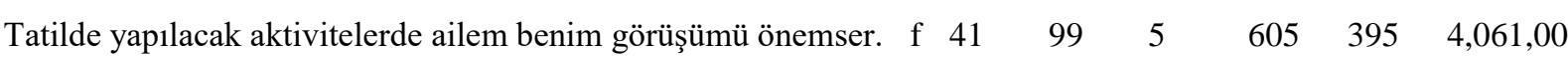




\begin{tabular}{llllllll}
\hline & $\% 3,6$ & 8,6 & 0,4 & 52,8 & 34,5 \\
\hline & f 42 & 95 & 7 & 608 & 393
\end{tabular}

Tatilde restoran yeri tercihinde ailem benim seçimlerimi

$4,061,00$
önemser.

\% 3,7 $\quad 8,3 \quad 0,6 \quad 53,1 \quad 34,3$

f $\quad 36 \quad 98 \quad 13 \quad 606 \quad 392$

Tatilde yemek menüleri tercihinde ailem benim seçimlerimi önemser.

$4,060,98$

\begin{tabular}{rrrrrrrrr}
\hline & f & 45 & 105 & 17 & 600 & 378 \\
& & & & & & & & \\
\hline
\end{tabular}

Tatilde ulaşım aracı tercihinde ailem benim seçimlerimi önemser.\% 3,9 $\quad 9,2 \quad$ 1,5 $\quad$ 52,4 $\quad 33,0$

Tatil İhtiyacı ve Bilgi Toplama Genel Ortalama=4,05

\begin{tabular}{|c|c|}
\hline & f $491036 \quad 603 \quad 384$ \\
\hline \multirow[t]{2}{*}{ Tatilde kaç gün kalacağımız konusunda ailem benim fikrimi alır. } & $\%$ 4,3 9,0 0,5 52,7 33,5 \\
\hline & f 5110113598382 \\
\hline \multirow[t]{2}{*}{ Tatilde kalış süremizin uzatılmasında ailem benim fikrimi alır. } & $\%$ 4,5 8,8 1,1 52,2 33,4 \\
\hline & f 541047601379 \\
\hline Tatilde kalış süremizin kısaltılmasında ailem benim fikrimi alır. & $\%$ 4,7 9,1 $0,652,533,1$ \\
\hline
\end{tabular}

Tatil Süresi Planlama Genel Ortalama=4,01

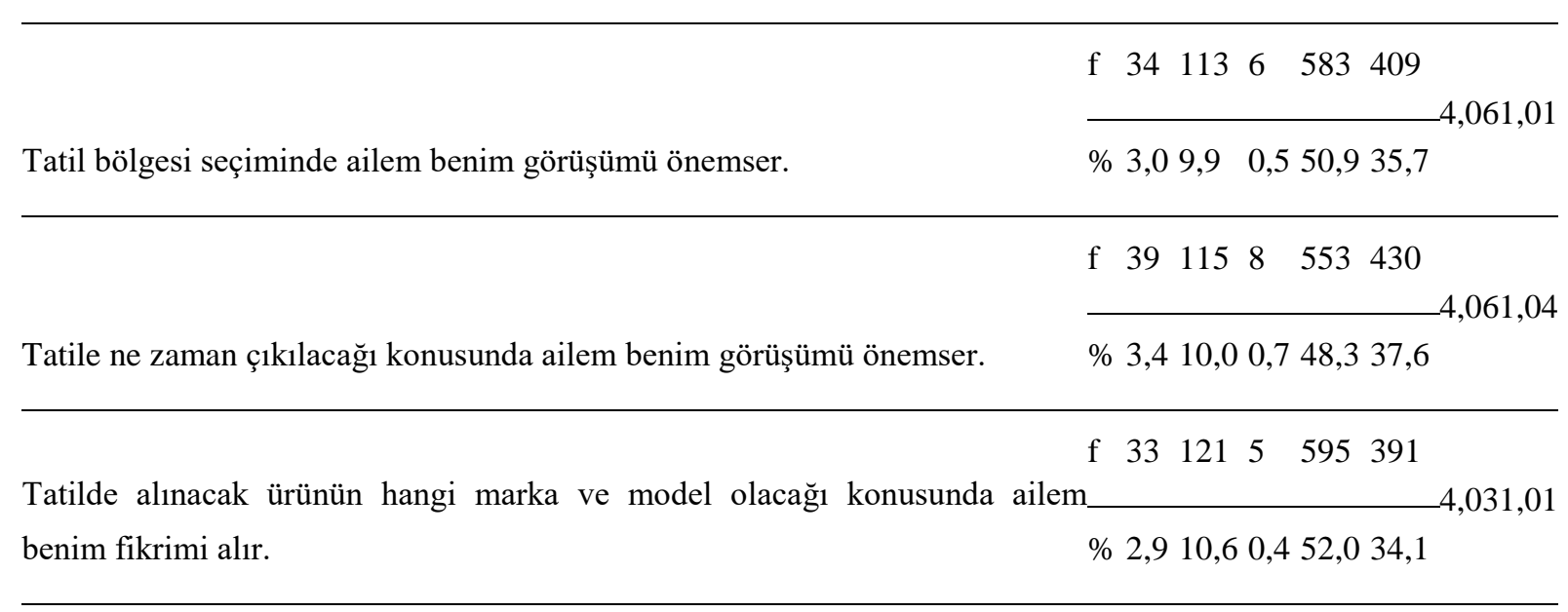


Tablo 6' da yer alan gençlerin ailelerin tatil karar sürecinde gençlerin etkisi algısı incelendiğinde, ailelerin tatil karar sürecinde gençlerinin etkisinin yüksek düzeyde $(\bar{X}=3,91)$ olduğu belirlenmiştir. Katılımcıların ailelerin tatil karar sürecinde gençlerin etkisi alg1 düzeylerinin alt boyut algıları incelendiğinde, Tatil ihtiyacı ve bilgi toplama alt boyutuna ait algılarının yüksek düzeyde $(\bar{X}=\mathbf{4 , 0 5})$ olduğu belirlenmiştir. Tatil ihtiyacı ve bilgi toplama alt boyutuna ait en yüksek algıya sahip maddenin "Tatilde nereye gideceğimiz konusunda ailem benim görüşümü önemser" $(\overline{\boldsymbol{X}}=\mathbf{4 , 0 7})$ maddesi iken en düşük algıya sahip maddenin "Tatilde ulaşım aracı tercihinde ailem benim seçimlerimi önemser” $(\overline{\boldsymbol{X}}=\mathbf{4 , 0 1})$ maddesi olduğu görülmektedir. Tatil süresi planlama alt boyutuna ait algılarının yüksek düzeyde $(\bar{X}=\mathbf{4 , 0 1})$, olduğu belirlenmiştir. Tatil süresi planlama alt boyutuna ait en yüksek algıya sahip maddenin "Tatilde kaç gün kalacağımız konusunda ailem benim fikrimi alır" $(\overline{\boldsymbol{X}}=\mathbf{4 , 0 2})$ maddesi iken en düşük algıya sahip maddenin "Tatilde kalış süremizin kısaltılmasında ailem benim fikrimi alır” ( $\overline{\boldsymbol{X}}=\mathbf{4 , 0 0})$ maddesi olduğu görülmektedir. Tatile çıkma kararı ve hazırlık alt boyutuna ait algılarının yüksek düzeyde $(\bar{X}=\mathbf{4 , 0 3})$ olduğu belirlenmiştir. Tatile çıkma kararı ve hazırlık alt boyutuna ait en yüksek algıya sahip maddelerin "Tatil bölgesi seçiminde ailem benim görüşümü önemser" ve "Tatile ne zaman çıkılacağı konusunda ailem benim görüşümü önemser” $(\overline{\boldsymbol{X}}=\mathbf{4 , 0 6})$ maddeleri iken en düşük algıya sahip maddenin "Tatil için alınacak ürünün ne zaman alınacağı konusunda ailem benim fikrimi önemser" ( $\bar{X}=\mathbf{4 , 0 1})$ maddesi olduğu görülmektedir.

Tablo 7: Ailelerin Tatil Karar Sürecinde Gençlerin Etkisi Alt Boyutları Arasındaki İlişkiyi Belirleyen Pearson Korelasyon Katsayısı Sonuçları

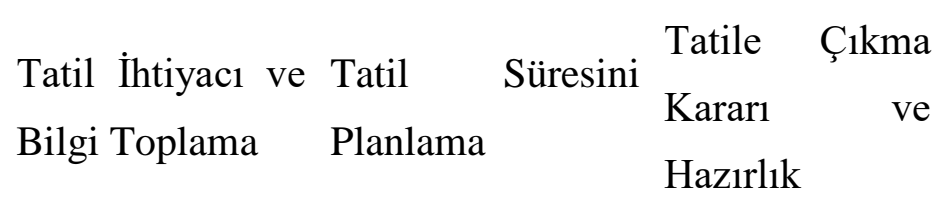

$\begin{array}{lllll}\text { Tatil İhtiyacı ve Bilgi Toplama } & r & 1 & 0,897^{* *} & 0,137^{* *}\end{array}$


Tatil Süresini Planlama
r $\quad 0,897 * *$
1
0,106**

\begin{tabular}{lll}
\hline p & 0,000 & 0,000
\end{tabular}

r $0,137^{* *} \quad 0,106^{* *} \quad 1$

Tatile Çıkma Kararı ve Hazırlık
p $\quad 0,000$
0,000

${ }^{* *} \mathrm{p}<0,01$

$\mathbf{H}_{\mathbf{0}}$ : Ailelerin tatil karar sürecinde gençlerin etkisi alt boyutları arasında anlamlı bir ilişki yoktur.

$\mathbf{H}_{1}$ : Ailelerin tatil karar sürecinde gençlerin etkisi alt boyutları arasında anlamlı bir ilişki vardir.

Ailelerin tatil karar sürecinde gençlerin etkisi alt boyutları arasındaki ilişkiyi incelemek için yapılan pearson korelasyon katsayısı sonuçlanı incelendiğinde, Tatil ihtiyacı ve bilgi toplama ile tatil süresini planlama arasında pozitif yönlü çok yüksek kuvvetli bir ilişki vardır. $(\mathrm{p}<0,001)(0,80<\mathrm{r}<1) \quad(\mathrm{r}=0,897)$. Yani başka bir deyişle Tatil ihtiyacı ve bilgi toplama algısında bir artış olduğunda tatil süresini planlama algısının artabileceği belirlenmiştir. $\mathrm{Bu}$ durumun tersi de doğrudur. Tatil ihtiyacı ve bilgi toplama ile tatile çıkma kararı ve hazırlık arasında pozitif yönlü çok düşük kuvvetli bir ilişki vardır. $\quad(p<0,001) \quad(0<\mathrm{r}<0,20)$ $(\mathrm{r}=0,137)$. Yani başka bir deyişle Tatil ihtiyacı ve bilgi toplama algısında bir artış olduğunda tatile çıkma kararı ve hazırlık algısının artabileceği belirlenmiştir. Bu durumun tersi de doğrudur. Tatile çıkma kararı ve hazırlık ile tatil süresini planlama arasında pozitif yönlü çok düşük kuvvetli bir ilişki vardır. $(\mathrm{p}<0,001)(0<\mathrm{r}<0,20)(\mathrm{r}=0,106)$. Yani başka bir deyişle Tatile çıkma kararı ve hazırlık algısında bir artış olduğunda tatil süresini planlama algısının artabileceği belirlenmiştir. Bu durumun tersi de doğrudur.

\section{Sonuç ve Tartışma}

$\mathrm{Bu}$ çalışma 15-24 yaş arası gençlerin ailelerin tatil karar verme sürecine etkilerini ölçmek amacıyla yapılan nadir çalışmalardan olması sebebiyle önemlidir. Çalışmada Ankara ilinin seçilmesinin temel sebebi bu ilde yaşayan gençlerin çoğunlukta olmasıdır. Araştırmanın daha önce yapılmış çalışmalardan farklı olarak gençler üzerine yapılmış çalışmaların azlığı bakımından tatil karar verme süreci ile ilgili yazına katkı sağlayabileceği düşünülmektedir.

Tatil karar verme süreci aşamalarına baktığımızda, ihtiyacın ortaya çıkması, bilgi toplama ve alternatiflerin değerlendirilmesi ve son olarak da satın alma aşamalarının önemli olduğu 
görülmüştür. Bu kavramlardan yola çıkılarak bu çalışmada, Tatil ihtiyacı ve bilgi toplama, Tatil süresi planlama ve Tatile çıkma kararı ve hazırlık aşamalarına yer verilmiştir. Çalışmada yapılan testler sonucunda 15-24 yaş arası gençlerin bu aşamalar üzerinde etkili oldukları ortaya çıkmıştır. Gençlerin ailelerin tatil karar verme sürecinde önemli belirleyici rolleri olduğu söylenebilir. Özelikler tatil ihtiyacı ve bilgi toplama ile tatil süresini planlama konusunda gençlerin çok yüksek kuvvetli etkileri olduğunu söylemek mümkündür.

Çalışma için hazırlanan anketler Ankara ilinde yaşayan 15-24 yaş arası gençler tarafından doldurulmuştur. Anket çalışmasının uygulamasında çoğunlukla gençlere yüz yüze görüşülerek veya eposta yoluyla ulaşılmıştır.

Geçmişten günümüze baktığımızda sosyal, kültürel, ekonomik yaşanan değişikliklerden ailenin de yapısal ve kültürel olarak etkilendiğini görmekteyiz. Geçmişte daha kalabalık yapıya sahip olan ailelerin yerini günümüzde çekirdek aile olarak adlandırdığımız aile yapısı almıştır. Ailede yaşayan bireylerin sayısı gittikçe azalmış, bireyler birbirinden bağımsız hareket etmeye başlamıştır. Ailede hüküm süren davranış şekilleri ailedeki gençleri de etkilemiş, ekonomik gelirin yüksek olduğu ailelerde kendi kararlarını alabilen gençler ortaya çıkmıştır. Ailelerin gençlere karşı tutumları değişmiş, neredeyse onların her isteklerini yerine getiren aileler ortaya çıkmıştır. Ailelerin gençlere yaklaşımındaki değişimlerinden dolayı gençler daha bağımsız hareket edebilen bireyler haline dönüşmüşlerdir. Tüm bunların sonucu olarak ailelerin karar süreçlerinde neredeyse her alanda etkili olan gençlerin, ailelerin tatil kararlarında ne derece etkili olduklarını tespit etmek amacıyla Ankara ilinde yaşan 1160 gence anket çalışması yapılmıştır. Çalışmada elde edilen bulgulardan yola çıkılarak, gençlerin aileleri üzerindeki etkilerini anlamak amaciyla gençlere çeşitli sorular sorulmuştur.

Çalışmada dikkat çeken bir konu ise, gençlerin ailelerinden istekleri yerine getirilmediğinde verdikleri tepkiler ailelerin satın alma eylemi konusundaki tutumlarında etkili olabilmektedir. Gençlerin istekleri olmadığında verdikleri tepkiler sonucu ailelerin fikirlerinde ve tutumlarında değişiklikler yaşandığı söylenebilir. Çalışmada elde edilen bulgulara göre, ankete cevap veren çoğunluğun erkekler olduğu ve aile içi gelir düzeyinin \%23,3'le yüksek olduğu görülmüştür. Ailedeki meslek gruplarına bakıldığında Akademik personel, Memur ve Sağlık alanında çalışan ve genelde alım gücü yüksek mesleklerdeki kişiler tercih edilmiştir. Ailedeki gençlerin tatil karar sürecinde en çok tatile ne zaman çıkılacağı ve tatilde nereye gidileceği konusunda etkili oldukları görülmektedir. Ailedeki gençlerin, istediğim şey alınmadığında tepki gösteririm ve ailemdeki başka bireyi ikna etmek için çabalarım, şeklindeki ifadelere vermiş oldukları cevaplar aslında tam anlamıyla ailelerinden bağımsız satın alma sürecini gerçekleştiremediklerini göstermektedir. Gençler tatilde yapılacak aktiviteler, restoran yeri seçiminde ve yemek menüleri seçiminde genellikle aynı görüşü 
paylaşmışlardır. Ancak diğer bulgular incelendiğinde tatilde ulaşım aracı tercihinde ve tatilde kullanılacak ürünün hangi marka ve model olacağı konusunda hem fikir olmadıkları görülmektedir. Gençlerin cinsiyetlerinin ve yaşının ailelerin tatil karar sürecinde rol oynağı görülmektedir. Araştırmada ki temel amaç, ailelerin tatil karar sürecine gençlerin ne derecede ve tatilde hangi alanlarda etkili olduğunu belirleyerek, çeşitli işletmelere veya ailelere fayda sağlamaktır. Günümüz gençlerinin tatil karar sürecinde ne gibi faktörler üzerinde etkili olduklarını göstererek kıyaslama yapmalarına yardımcı olmaktır.

Yapmış olduğumuz bu çalışma gençlerin tatil karar sürecinde ne gibi eğilimleri olduğu hakkında bilgi verirken, işletmeler açısından da ilerde gençler için yapacakları uygulamalara 1şık tutabilir. Bu çalışma stratejik kararlar almak isteyen işletmeler ve ailelerin tatil satın alma kararlarında gençlerin etkisini bilme gereği duyan pazarlamacılara fayda sağlamaktadır. Çalışma tatil beldelerinde bulunan işletmeler açısından gençlerin istek ve ihtiyaçlarına cevap verebilmeleri bakımından fayda sağlayabilir. Araştırmanın diğer bir katkısı ise, ailelerin tatil karar sürecine gençlerin etkilerini belirmeye yönelik ileride yapılacak olan çalışmalara katkı sağlayacaktır.

\section{Kaynakça / References}

Aydın, K. (2007). Uluslararası ve Küresel Pazarlamada Kültürel Etkiler. İstanbul: Nobel Yayın Dağıtım.

Can, H.; Tuncer, D. \& Ayhan, D. Y. (2002). Genel Işsletmecilik Bilgileri. Ankara: Siyasal Kitabevi.

Durmuş, B.; Yurtkoru, E. \& Çinko, M. (2013). Sosyal Bilimlerde Spss'le Veri Analizi. İstanbul: Beta Yayıncilik.

Emir, O. \& Pekyaman, A. (2010). Çocuklu Ailelerin Otel İşletmesi Seçiminde Etkili Olan Faktörler: Afyonkarahisar'da Bir Uygulama, Yönetim ve Ekonomi, 17(2), 159-181.

İçöz, O. (1996). Turizm İşletmelerinde Pazarlama. Ankara: Anatolia Yayıncılık

Koç, E. (2011). Tüketici Davranışı ve Pazarlama Stratejileri Global ve Yerel Yaklaşım. Ankara: Seçkin Yayıncılık 
Koç, E. (2013). Tüketici Davranışı ve Pazarlama Stratejileri Global ve Yerel Yaklaşım. Ankara: Seçkin Yayıncılık

Kotler, P. (2000). Marketing Management, Millenium Edition, A Pearson Education Company Upper Saddle River, New Jersey.

M. Tiago \& F. Tiago (2013). Tourism and Management Studies, 9(1), 31.

Marshall, G, (1999). Sosyoloji Sözlüğü, İstanbul: Bilim ve Sanat Yayınları

Nirun, N. (1994). Sistematik Sosyoloji Yönünden Aile ve Kültür, Ankara: Atatürk Kültür Dil ve Tarih Yüksek Kurumu Yayınları.

Önder, A. (2003). Ailede İletişim, İstanbul: Morpa Kültür Yayınları

Rızaoğlu, B. (2003). Turizm Davranışı. (2. Basım), Ankara: Detay Yayıncılık.

Sayın, Ö. (1990). Aile Sosyolojisi, Ailenin Toplumdaki Yeri. İzmir: Ege Üniversitesi Basımevi T.C. Aile ve Sosyal Politikalar Bakanlığı (2013). Türkiye Aile Yapısı Araştırması Tespitler, Öneriler, İstanbul.

Yörükoğlu, A. (2007). Değişen Toplumda Aile ve Çocuk, İstanbul: Özgür Yayınları. 